\title{
ANALISIS USAHATANI TERPADU TANAMAN PADI (Oriza sativa $L$ ) DAN TERNAK ITIK PETELUR \\ (Studi Kasus di Kelompok Mukti Tani Desa Banjarsari Kecamatan Sukaresik Kabupaten Tasikmalaya)
}

\author{
Oleh: \\ Ai Indah Perwati ${ }^{1}$, Dedi Herdiansah $\mathbf{S}^{2}$, Mochamad Ramdan ${ }^{3}$ \\ ${ }^{1,2,3}$ Fakultas Pertanian Universitas Galuh
}

\begin{abstract}
ABSTRAK
Penelitian ini dilaksanakan dengan tujuan untuk mengetahui : (1) besarnya biaya dan penerimaan usahatani terpadu tanaman padi dan ternak itik petelur, (2) besarnya pendapatan usahatani terpadu tanaman padi dan ternak itik petelur, (3) besarnya $R / C$ usahatani terpadu tanaman padi dan ternak itik petelur. Penelitian ini dilaksanakan dengan menggunakan metode studi kasus, dengan mengambil kasus pada Kelompok Mukti Tani di Desa Banjarsari Kecamatan Sukaresik Kabupaten Tasikmalaya. Sampel penelitian untuk responden diambil secara sengaja sebanyak 7 orang menggunakan metode sensus. Hasil penelitian menunjukkan : (1) Rata-rata biaya total per luas lahan per satu kali tanam yang dikeluarkan petani pada usahatani terpadu tanaman padi dan ternak itik petelur sebesar Rp. 16.864.174,60. Rata-rata penerimaan usahatani terpadu tanaman padi dan ternak itik petelur per luas lahan per satu kali tanam sebesar Rp. 28.157.157,14. (2) Pendapatan petani pada usahatani terpadu tanaman padi dan ternak itik petelur per luas lahan per satu kali tanam sebesar Rp. 11.292.982,54. (3) Besarnya $R / C$ pada usahatani terpadu tanaman padi dan ternak itik petelur per luas per satu kali tanam sebesar 1,67.
\end{abstract}

Kata Kunci : Usahatani Terpadu, Pendapatan, $R / C$.

\section{PENDAHULUAN}

Petani di Kabupaten Tasikmalaya disamping bercocok tanam padi juga melakukan usaha sampingan dengan beternak, ternak yang dipelihara salah satunya adalah ternak itik. Ternak itik merupakan salah satu komoditas yang memiliki potensi dan peran yang cukup stategis dalam penyediaan protein hewani yang mudah didapat dan dengan harga terjangkau. Keberhasilan pengembangan itik khususnya dalam usaha pembibitan itik membutuhkan penanganan yang lebih intensif dan masih perlu campur tangan pemerintah terutama dalam menangani kebutuhan pakan sehingga dapat menekan biaya pakan yang relatif tingg. (Dinas Peternakan Perikanan dan Kelautan Kabupaten Tasikmalaya, 2015).

Kelompok Mukti Tani yang beralamat Kampung Cinusa Desa Banjarsari Kecamatan Sukaresik adalah satu-satunya kelompok di Kabupaten Tasikmalaya yang menjalankan pola usahatani terpadu antara padi dan itik Petelur. Usahatani terpadu padi dan itik petelur adalah pola integrasi yang dapat menghasilkan pendapatan harian bagi petani sehingga dapat membantu petani dalam memenuhi kebutuhan hidup setiap harinya.
Kelompok Mukti Tani merupakan kelompok yang seluruh anggotanya adalah petani. Bertani merupakan pekerjaan utama bagi anggota kelompok, disamping bercocok tanam padi sebagai usaha pokok juga memelihara ternak itik untuk menambah nilai pendapatan anggota kelompok pada satu kawasan. Hal ini didukung dengan adanya pemanfaatan secara terpadu yaitu tanaman padi dan ternak itik. Dimana tanaman padi dapat menghasilkan dedak halus, bekatul, menir dan sekam yang bisa dimanfaatkan sebagai makanan ternak itik, sedangkan selain daging dan telur, ternak itik juga menghasilkan limbah berupa feses (kompos) dan urin (pupuk cair) yang sangat bermanfaat untuk tanaman padi. Sehingga dengan adanya perpaduan antara keduanya maka semua input dapat dijadikan output kembali untuk meningkatkan pendapatan petani. Usaha yang dilakukan kelompok memberikan nilai tambah dan saling mendukung antara usaha pokok menanam tanaman padi dan beternak itik dan saling memberi manfaat sehingga didapatkan hasil yang lebih baik pada kedua usaha yang dijalankan tersebut. 


\section{METODE PENELITIAN}

\section{Jenis Penelitian}

Jenis penelitian yang digunakan adalah metode study kasus, dengan mengambil kasus pada Kelompok Mukti Tani Desa Banjarsari Kecamatan Sukaresik Kabupaten Tasikmalaya.

Penentuan responden dalam penelitian ini adalah semua anggota kelompok dengan menggunakan metode penarikan sampel jenuh atau sensus. Anggota kelompok Mukti Tani yang berada di Kampung Cinusa Desa Banjarsari Kecamatan Sukaresik sebanyak 7 orang. Sugiyono (2007) sampling jenuh atau sensus adalah teknik penentuan sampel bila semua anggota digunakan sebagai sampel.

\section{Rancangan Analisis Data}

Rancangan analisis data disesuaikan dengan data yang tersedia dan tujuan yang hendak dicapai. Analisis yang dilakukan adalah biaya, penerimaan, pendapatan danR/C.

a. Analisis Biaya total

$\mathrm{TC}=\mathrm{FC}+\mathrm{VC}$

dimana :

$\mathrm{TC}=$ Total Cost $($ Biaya Total $)$

$\mathrm{FC}=$ Fixed Cost (Biaya Tetap Total)

$\mathrm{VC}=$ Variabel Cost (Biaya Variabel Total)

b. Analisis Penerimaan

$\mathrm{TR}=\mathrm{Y}$.Py

dimana :

$\mathrm{TR}=$ Total Revenue (penerimaan usahatani)

$\mathrm{Y}=$ Output (produksi yang diperoleh)

Py = Price (harga output)

c. Analisis Pendapatan

$\mathrm{I}=\mathrm{TR}-\mathrm{TC}$
Dimana :

I = Income (Pendapatan)

$\mathrm{TR}=$ Total Revenue (Total Penerimaan)

$\mathrm{TC}=$ Total Cost (Total Pengeluaran)

d. Analisis R/C dan Keuntungan Usaha

$R C$ ratio $=\frac{T R}{T C}$

Dimana :

$\mathrm{RC}$ ratio $=$ Return Cost Ratio $($ Rasio

penerimaan - biaya)

TR= Total Revenue (Penerimaan total)

TC = Total cost (Biaya total)

HASIL PENELITIAN DAN PEMBAHASAN

Biaya Produksi dan Penerimaan Usahatani Terpadu Tanaman Padi dan Itik Petelur

Biaya yang dikeluarkan oleh petani terdiri dari biaya tetap (fixed cost) dan biaya tidak tetap (variable cost). Biaya tetap dalam Usahatani Terpadu Tanaman Padi dan Itik Petelur ini meliputi Biaya penyusutan, pengairan serta Pajak Bumi dan Bangunan (PBB). Adapun biaya variabel yang dibutuhkan selama berusahatani terpadu dalam 1 (satu) kali musim tanam adalah biaya benih, pupuk, obat-obatan/pestisida, dan tenaga kerja. Untuk proses budidaya itik petelur biaya tetapnya hanya biaya penyusutan karena budidaya itik petelur merupakan usaha sampingan dan diusahakan pada lahan pinggir sawah, sedangkan untuk biaya variabel budidaya itik petelur meliputi bibit ternak, pakan konsentrat, pakan lokal (jagung giling dan dedak halus) dan obat-obatan.

Rata-rata biaya produksi Usahatani Terpadu Tanaman Padi dan Itik Petelur per per luas tanam satu kali musim tanam (4 bulan) untuk lebih jelasnya dapat dilihat pada Tabel 1.

Tabel 1.Rata-Rata Biaya Produksi pada Usahatani Terpadu Tanaman Padi dan Itik Petelur per Luas Lahan Per Musim Tanam di Kelompok Mukti Tani Desa Banjarsari Kecamatan Sukaresik Tahun 2015.

\begin{tabular}{|c|l|r|r|}
\hline No & \multicolumn{1}{|c|}{ Komponen Biaya } & $\begin{array}{r}\text { Jumlah Biaya } \\
(\text { Rp) }\end{array}$ & $\begin{array}{r}\text { Persentase } \\
(\%)\end{array}$ \\
\hline A & Usahatani Padi & & \\
1 & Biaya Tetap & $84.285,71$ & 0,50 \\
& a. Biaya Penyusutan & $74.246,03$ & 0,44 \\
& b. PBB & $105.714,29$ & 0,63 \\
& c. Pengairan & $264.246,03$ & \\
2 & Total Biaya Tetap & & \\
Biaya Variabel & & 0,51 \\
\hline
\end{tabular}




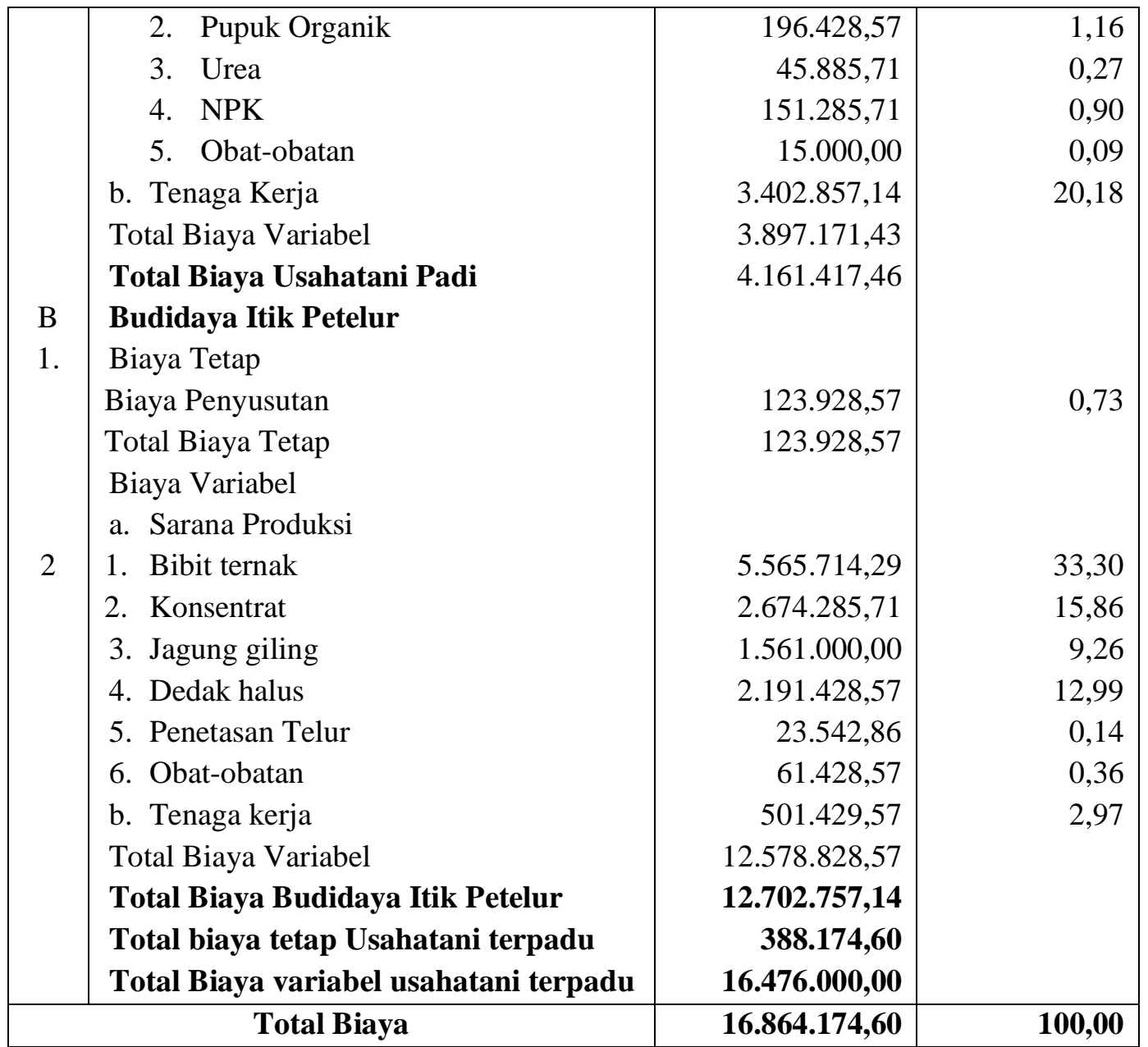

Berdasarkan Tabel 1 Biaya pada sistem usahatani terpadu tanaman padi dan itik petelur di Kelompok Mukti Tani antara lain :

a. Biaya Usahatani Padi

Rata-rata besarnya biaya tetap pada usahatani padiper luas lahan per satu kali musim tanam sebesar Rp. 264.246,03. Ratarata besarnya biaya variabel pada usahatani padiper luas lahan per satu kali musim tanam sebesar Rp. 3.897.171,43. Rata-rata biaya total usahatani padi per luas lahan per satu kali tanam yang dikeluarkan petani pada usahatani padi sebesar Rp. 4.161.417,46.

b. Biaya Budidaya Itik Petelur

Rata-rata besarnya biaya tetap budidaya itik petelurper luas lahan per satu kali musim tanam sebesar Rp. 123.928,57. Rata-rata besarnya biaya tetap budidaya itik petelurper luas lahan per satu kali musim tanam sebesar Rp. $12.578 .828,57$. Rata-rata biaya total per luas lahan per satu kali tanam yang dikeluarkan petani pada budidaya itik petelur sebesar Rp. 12.702.757,14. c. Biaya Usahatani Terpadu Tanaman Padi dan Itik Petelur

Rata-rata besarnya biaya tetap petani yang berusahatani terpadu tanaman padi dan itik petelur per luas lahan per satu kali musim tanam sebesarRp. 388.174,60. Sedangkan untuk rata-rata biaya variabel untuk usahatani terpadu tanaman padi dan budidaya itik petelur per luas lahan per satu kali musim tanam sebesar Rp. 16.476.000,00.Rata-rata biaya total usahatani terpadu tanaman padi dan itik petelur per luas lahan per satu kali musim tanam sebesar Rp. 16.864.174,60.

Penerimaan diperoleh dari jumlah seluruh produk padi dan produk budidaya itik petelur yang dihasilkan dikalikan dengan harga satuan pada saat penelitian, rata-rata hasil produksi dari usahatani terpadu tanaman padi dan itik petelur per satu kali musim tanam (satu kali proses produksi) dapat dilihat pada Tabel 2. 
Tabel 2.Rata-rata Produksi, Harga Jual, dan Penerimaan pada Usahatani Terpadu Tanaman Padi dan Itik Petelur Per Luas Lahan Per Satu Kali Musim Tanam di Kelompok Mukti Tani Desa Banjarsari Kecamatan Sukaresik Tahun 2015.

\begin{tabular}{|c|l|r|r|r|r|}
\hline No & \multicolumn{1}{|c|}{ Komponen } & \multicolumn{1}{c|}{ Jumlah } & Satuan & Harga Jual (Rp) & \multicolumn{1}{c|}{ Penerimaan } \\
\hline \multirow{2}{*}{2} & Usahatani Padi & & & & \\
& Produksi & $1.816,00$ & Kg & $5.200,00$ & $9.443 .200,00$ \\
& Budidaya Itik Petelur & & & & \\
& a. Telur & $6.753,29$ & Butir & $1.900,00$ & $12.831 .242,86$ \\
& b. DOD & 45,29 & Ekor & $7.000,00$ & $317.000,00$ \\
& c. Itik Petelur & 69.57 & Ekor & $80.000,00$ & $5.565 .714,29$ \\
\hline \multicolumn{4}{|c|}{ Total Penerimaan } \\
\hline
\end{tabular}

Tabel 2 menunjukkan bahwa penerimaan pada usahatani terpadu tanaman padi dan itik petelur petani antara lain :

a. Penerimaan Usahatani Padi

Rata-rata Penerimaan usahatani padi per luas lahan per satu kali musim tanam dari produksi padi kering giling adalah 1.816 kilogram, harga jual padi pada saat penelitian adalah Rp. 5.200,00 per kilogram, maka ratarata penerimaan dari usahatani padi per satu kali musim tanam adalah Rp. 9.443.200,00.

b. Penerimaan Budidaya Itik

Petelur produksi telur, DOD dan itik petelur. Itik petelur disini dimaksudkan adalah ternak itik yang dibeli untuk bibit yang hanya diproduksikan selama 4 bulan saja dimana usia produksi itik kurang lebih mencapai 2 tahun, untuk ternak itik yang dijual pada saat masih usia produksi tidak mengalami penurunan harga, bahkan cenderung mengalami kenaikan karena masih menuju usia produksi tertinggi. Rata-rata produksi telur per satu kali produksi adalah $6.753,29$ butir, harga jual telur pada saat penelitian adalah Rp. 1.900,00 per butir, maka rata-rata penerimaan dari telur per satu kali produksi adalah Rp. 12.831.242,86. Rata-rata produksi DOD per satu kali produksi adalah 45,29 ekor, harga jual DOD pada saat penelitian adalah Rp. 7.000,00 per ekor, maka rata-rata penerimaan dari telur per satu kali produksi adalah Rp. 317.000,00. Rata-Rata penerimaan dari itik petelur adalah 69,57 ekor, harga jual pada saat penelitian adalah Rp. $80.000,00$ per ekor sama dengan harga beli, maka rata-rata penerimaan dari itik petelur per satu kali proses produksi adalah Rp. 5.565.714,29,00. Rata-rata penerimaan total budidaya itik petelur per satu kali musim tanam sebesar Rp. 18,713.957,14.

c. Penerimaan Usahatani Terpadu Tanaman Padi dan Itik Petelur

Penerimaan pada usahatani terpadu tanaman padi dan itik petelur adalah penjumlahan dari penerimaan usahatani padi dengan penerimaan budidaya itik petelur. Dari hasil penjumlahan rata-rata penerimaan usahatani padi dan budidaya itik maka diperoleh total penerimaan sebesar $\mathrm{Rp}$. 28.157.157,14.

\section{Pendapatan Usahatani Terpadu Tanaman Padi dan Itik Petelur}

Pendapatan atau keuntungan adalah selisih antara penerimaan dengan biaya produksi total. Rata-rata penerimaan, biaya total dan pendapatan dari usahatani terpadu tanaman padi dan itik petelur per satu kali musim tanam dapat dilihat pada Tabel 3.

Tabel 3. Rata-rata Penerimaan, Produksi Total dan Pendapatan pada Usahatani Terpadu Tanaman Padi dan Itik Petelur Per Luas Lahan Per Satu Kali Musim Tanam di Kelompok Mukti Tani Desa Banjarsari Kecamatan Sukaresik Tahun 2015.

\begin{tabular}{|c|l|r|r|r|}
\hline No & Komponen & $\begin{array}{c}\text { Usahatani Padi } \\
(\mathbf{R p})\end{array}$ & $\begin{array}{c}\text { Budiaya Itik } \\
\text { Petelur (Rp) }\end{array}$ & $\begin{array}{c}\text { Jumlah } \\
(\mathbf{R p})\end{array}$ \\
\hline 1 & Penerimaan & $9.433 .200,00$ & $18.713 .957,14$ & $28.157 .157,14$ \\
2 & Total Biaya & $4.161 .417,46$ & $12.702 .757,14$ & $16.864 .174,60$ \\
3 & Pendapatan & $5.271 .782,54$ & $6.011 .200,00$ & 11.292 .982 .54 \\
\hline
\end{tabular}


Berdasarkan Tabel 3, Pendapatan pada usahatani terpadu tanaman padi dan itik petelur di Kelompok Mukti Tani antara lain :

a. Pendapatan Usahatani Padi

Rata-rata penerimaan pada usahatani padi per luas lahan per satu kali musim tanam sebesar Rp. 9.433.200,00 dan rata-rata total biaya pada usahatani padi per luas lahan per satu kali musim tanam sebesar Rp. 4.161.417,46. Rata-rata pendapatan usahatani padi per luas lahan per satu kali musim tanam sebesar Rp. 5.271.782,54.

b. Pendapatan Budidaya Itik Petelur

Rata-rata penerimaan pada budidaya itik petelur per luas lahan per satu kali musim tanam sebesar Rp. 18.713.957,14 dan rata-rata total biaya pada budidaya itik petelur per luas lahan per luas lahan per satu kali musim tanam sebesar Rp. 12.702.757,14,00. Ratarata pendapatan budidaya itik petelur per luas lahan per satu kali musim tanam sebesar Rp. 6.011.200,00.

c. Pendapatan Usahatani Terpadu Tanaman Padi dan Itik Petelur

Rata-rata Pendapatan usahatani padi per satu kali musim tanam sebesar Rp. 5.271.782,54 dan pendapatan budidaya itik petelur per satu kali musim tanam sebesar Rp. 6.011.200,00. Rata-rata pendapatan usahatani terpadu tanaman padi dan itik petelur per satu kali musim tanam sebesar Rp. 11.292.982,54.

\section{Analisis R/C}

$\mathrm{R} / \mathrm{C}$ (revenue/cost) merupakan perbandingan antara penerimaan yang diperoleh dengan besarnya biaya yang dikeluarkan pada usaha tersebut, $\mathrm{R} / \mathrm{C}$ usahatani terpadu tanaman padi dan itik petelur di Kelompok Mukti Tani Desa Banjarsari Kecamatan Sukaresik dapat dilihat pada Tabel 4.

Tabel 4. Analisis R/C pada Usahatani Terpadu Tanaman Padi dan Itik Petelur Per Luas Lahan Per Satu Kali Musim Tanam di Kelompok Mukti Tani Desa Banjarsari Kecamatan Sukaresik

Tahun 2015.

\begin{tabular}{|c|l|r|r|r|}
\hline No & Komponen & $\begin{array}{r}\text { Usahatani Padi } \\
(\mathbf{R p})\end{array}$ & $\begin{array}{c}\text { Budiaya Itik } \\
\text { Petelur (Rp) }\end{array}$ & \multicolumn{1}{c|}{$\begin{array}{c}\text { Jumlah } \\
(\mathbf{R p})\end{array}$} \\
\hline 1 & Penerimaan & $9.433 .200,00$ & $18.713 .957,14$ & $28.157 .157,14$ \\
2 & Total Biaya & $4.161 .417,46$ & $12.702 .757,14$ & $16.864 .174,60$ \\
3 & R/C & 2,27 & 1,47 & 1,67 \\
\hline
\end{tabular}
lain:

Berdasarkan Tabel 4, didapat $\mathrm{R} / \mathrm{C}$ antara

a. R/C Usahtani Padi

Dari rata-rata biaya produksi yang dikeluarkan petani pada usahatani padi per luas lahan per satu kali musim tanam sebesar Rp. 4.161.417,46 diperoleh rata-rata penerimaan usahatani padi per luas lahan per satu kali musim tanam sebesar Rp. 9.433.200,00 sehingga R/C dari usahatani padi sebesar 2,27.

b. R/C Budidaya Itik Petelur

Dari rata-rata biaya produksi yang dikeluarkan petani pada budidaya itik petelur per luas lahan per satu kali musim tanam sebesar Rp. 12.702.757,14 diperolehrata-rata penerimaan dari budidaya itik petelur per luas lahan per satu kali musim tanam sebesar Rp. 18.713.957,14 sehingga R/C dari budidaya itik petelur sebesar 1,47.

c. R/C Usahtani Terpadu Tanaman Padi dan Itik Petelur
Rata-rata biaya produksi yang dikeluarkan petani dalam sistem usahatani terpadu tanaman padi dan itik petelur sebesar Rp. 16.864.174,60 diperoleh penerimaan sebesar Rp. 28.157.157,14 sehingga R/C dari usahatani terpadu tanaman padi dan itik petelur per satu kali musim tanam sebesar 1,67 dengan kriteria keputusan bahwa usahatani terpadu tersebut menguntungkan.

Dari perhitungan diatas, sistem usahatani terpadu tanaman padi dan itik petelur pola integrasinya terwujud pada hubungan saling menguntungkan dimana tanaman padi menghasilkan dedak yang dapat digunakan untuk pakan ternak itik petelur dan ternak itik petelur menghasilkan kotoran itik yang dapat digunakan sebagai pupuk organik bagi tanaman padi.

\section{KESIMPULAN DAN SARAN \\ Kesimpulan}

Berdasarkan hasil penelitian dan pembahasan, maka dapat ditarik kesimpulan sebagai berikut: 
1. Rata-rata biaya total per luas lahan per satu kali musim tanam yang dikeluarkan petani usahatani terpadu tanaman padi dan itik petelur di Kelompok Mukti Tani Desa Banjarsari Kecamatan Sukaresik sebesar Rp. 16.864.174,60. Rata-rata penerimaan usahatani terpadu tanaman padi dan itik petelur per luas lahan per satu kali musim tanam Kelompok Mukti Tani Desa Banjarsari Kecamatan Sukaresik adalah Rp. 28.157.157,14.

2. Pendapatan petani usahatani terpadu tanaman padi dan itik petelur per satu kali musim tanam di Kelompok Mukti Tani Desa Banjarsari Kecamatan Sukaresik sebesar Rp. 11.292.982,54.

3. R/C dari petani usahatani terpadu tanaman padi dan itik petelur per satu kali musim tanam di Kelompok Mukti Tani Desa Banjarsari Kecamatan Sukaresik sebesar 1,67.

\section{Saran}

Berdasarkan kesimpulan maka disarankan petani terus mengusahaan usahatani terpadu tanaman padi dan ternak itik petelur pada lahan usahataninya dengan memperhatikan hal-hal sebagai berikut :

1. Mengingat penggunaan pupuk pada kelompok Mukti Tani antara lain pupuk organik sebanyak 1.355 kilogram per hektar, Urea sebanyak 71,57 kilogram per hektar dan NPK sebanyak 173,89 kilogram per hektar, sedangkan yang sesuai rekomendasi teknis adalah Urea sebanyak 200 kilogram per hektar, SP-36 sebanyak 100 kilogram per hektar dan KCL sebanyak 50 kilogram per hektar. Selain itu untuk mengoptimalkan produksi petani diharapkan menggunakan pupuk kandang yang sesuai dengan rekomendasi teknis sebanyak 1.500 kilogram per hektar.

2. Petani disarankan untuk lebih banyak memproduksi DOD (Day Old Duck) dari produksi telur yang memenuhi syarat untuk ditetaskan karena harganya relatif lebih tinggi yaitu Rp. 7.000,00 per ekor dibanding menjual langsung telur dengan harga Rp. $1.900,00$ per butir sehingga dapat meningkatkan pendapatan petani.

\section{DAFTAR PUSTAKA}

Dinas Peternakan Perikanan dan Kelautan Kabupaten Tasikmalaya. 2015. Laporan TriwulanI Tahun 2015. Tasikmalaya.

Direktorat Jenderal Peternakan dan Kesehatan Hewan. 2013. Pedoman Pelaksanaan Integrasi Unggas. Kementerian Pertanian. Jakarta.

Hamdani. 2008. Sistim Pertanian Terpadu untuk Peningkatan Produktivitas Lahan dan Kesejahteraan Petani. Serang

Hanafi. 2010. Analisa Belanja: Dasar-dasar Perhitungan dalam Keputusan Keuangan. Cetakan Kedua. Penerbit Bina Aksara. Jakarta.

Kariyasa. 2005. Analisis Permintaan dan Penawaran Daging Sapi di Indonesia Sebelum dan Saat Krisis. Malang.

Shinta, Agustina. 2010. Ilmu Usaha Tani. UB Press. Malang.

Siregar, Surya Amri. 2009. Analisis Pendapatan Peternak Sapi Potong di Kecamatan Strabat, Kabupaten Langkat. Fakultas Pertanian Universitas Sumatera Utara. Medan.

Sugiyono. 2007.Metode Penelitian Pendidikan Pendekatan Kuantitatif, Kualitatif dan R\&D. Alfabeta. Bandung. 